Mar. Drugs 2007, 5, 31-39

Marine Drugs

ISSN 1660-3397

(C) 2007 by MDPI

www.mdpi.org/marinedrugs

Full Original Paper

\title{
Monoindole Alkaloids from a Marine Sponge Spongosorites sp.
}

Baoquan Bao ${ }^{1,2}$, Ping Zhang ${ }^{1}$, Yoonmi Lee ${ }^{1}$, Jongki Hong ${ }^{3}$, Chong-O. Lee ${ }^{4}$ and Jee H. Jung ${ }^{1{ }^{*}}$

1 College of Pharmacy, Pusan National University, Busan 609-735, Korea

2 College of Traditional Mongolian Medicine, Inner Mongolia University for the Nationalities, Tongliao Inner Mongolia 028000, China; E-mail: baorchon@yahoo.com

3 College of Pharmacy, Kyung Hee University, Seoul 130-701, Korea

4 Korea Research Institute of Chemical Technology, Daejon 305-343, Korea

* Author to whom correspondence should be addressed. Tel., 82-51-510-2803; Fax: 82-51-513-6754;

E-mail: jhjung@pusan.ac.kr

Received: 5 June 2007 / Accepted: 23 June 2007 / Published: 25 June 2007

\begin{abstract}
Seven (1-7) monoindole derivatives were isolated from the $\mathrm{MeOH}$ extract of a marine sponge Spongosorites sp. by bioactivity-guided fractionation. The planar structures were established on the basis of NMR and MS spectroscopic analyses. Compounds 1-5 are unique indole pyruvic acid derivatives. Compounds 1-2 and 4-6 are isolated for the first time from a natural source although they were previously reported as synthetic intermediates. Compound $\mathbf{3}$ was defined as a new compound. Co-occurring bisindoles such as hamacanthins and topsentins might be biosynthesized by condensation of two units of these compounds. The compounds were tested for cytotoxicity against a panel of five human solid tumor cell lines, and compound 7 displayed weak activity.
\end{abstract}

Keywords: Marine sponge; Spongosorites; monoindole alkaloids; cytotoxicity.

\section{Introduction}

To date, dozens of simple monoindole derivatives were reported from marine sources, such as sponges [1-5], ascidians [6], bryozoans [7], bacteria [8], and fungi [9]. Some of these metabolites were reported to exhibit antibacterial [2,10], antifungal [3], and auxin [4] activities. 
In our previous study on cytotoxic compounds from the marine sponge Spongosorites sp., we isolated a series of bisindole alkaloids [11,12]. In our continuing search for cytotoxic metabolites from the same sponge, seven monoindole alkaloids were isolated. Compounds 1-2 and 4-6 were isolated for the first time from a natural source although they were previously reported as synthetic intermediates (Figure 1). Compound $\mathbf{3}$ was defined as a new compound. Herein we describe the structure elucidation and the biological evaluation of these compounds.

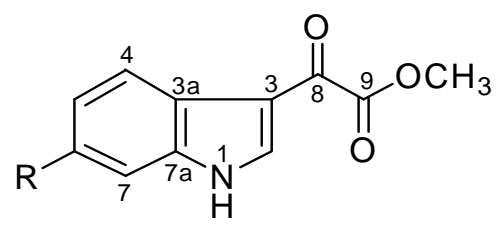

$\begin{array}{ll}1 & \mathrm{R}=\mathrm{Br} \\ 2 & \mathrm{R}=\mathrm{H} \\ 3 & \mathrm{R}=\mathrm{OH}\end{array}$

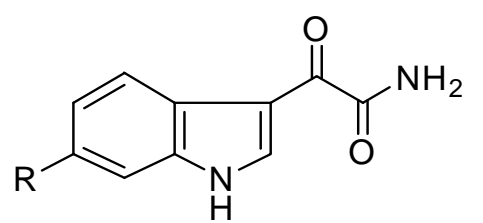

$4 \mathrm{R}=\mathrm{H}$

$5 \mathrm{R}=\mathrm{Br}$<smiles>[R]C(=O)c1c[nH]c2cc([R])ccc12</smiles>

$6 \mathrm{R}=\mathrm{OH}$

$7 \mathrm{R}=\mathrm{H}$

Figure 1. Seven (1-7) monoindole derivatives were isolated from the $\mathrm{MeOH}$ extract of a marine sponge Spongosorites sp.

\section{Result and discussion}

Compound 1 was isolated as a yellow, amorphous powder. The molecular formula was established as $\mathrm{C}_{11} \mathrm{H}_{8} \mathrm{BrNO}_{3}$ on the basis of the EIMS and NMR data. In the LREIMS of $\mathbf{1}$, a (M) ${ }^{+}$ion cluster was observed at $\mathrm{m} / \mathrm{z} 281 / 283$ in the ratio of 1:1 that is characteristic of a monobrominated compound. The NMR spectrum of $\mathbf{1}$ were reminiscent of reported indole alkaloids. ${ }^{11,12}$ Analysis of the ${ }^{1} \mathrm{H},{ }^{13} \mathrm{C}$, COSY, HMBC, and HSQC data, along with comparison of chemical shift values with those of known indole alkaloids, allowed us to establish a 6-bromoindol-3-yl residue as a partial structure of $\mathbf{1}$. The singlet at $\delta_{\mathrm{H}} 8.45(\mathrm{H}-2)$, and a spin system comprised of signals at $\delta_{\mathrm{H}} 8.07(1 \mathrm{H}, \mathrm{d}, J=8.0 \mathrm{~Hz}, \mathrm{H}-4), 7.40(1 \mathrm{H}, \mathrm{dd}$, $J=8.0,2.0 \mathrm{~Hz}, \mathrm{H}-5)$, and $7.73(1 \mathrm{H}, \mathrm{d}, J=2.0, \mathrm{H}-7)$ indicated the presence of a 6-bromoindol-3-yl moiety (Table 1$)$. Long-range correlations from H-4 $\left(\delta_{\mathrm{H}} 8.07\right)$ to C-3 $\left(\delta_{\mathrm{C}} 112.5\right)$ and C-6 $\left(\delta_{\mathrm{C}} 116.2\right)$, along with the COSY correlation between $\mathrm{H}-4$ and $\mathrm{H}-5$, and the long-range correlations from $\mathrm{H}-5\left(\delta_{\mathrm{H}} 7.40\right)$ to C-3a $\left(\delta_{\mathrm{C}} 124.8\right)$ and C-7 (115.5) strongly suggested the presence of a 6-bromoindol-3-yl moiety. The NMR signals at $\delta_{\mathrm{C}} 178.2(\mathrm{C}-8), \delta_{\mathrm{C}} 164.0(\mathrm{C}-9)$, and $\delta_{\mathrm{H}} 3.89\left(-\mathrm{OCH}_{3}, 3 \mathrm{H}\right)$, along with the HMBC correlations of $-\mathrm{OCH}_{3} / \mathrm{C}-9$, suggested an oxoacetic acid methyl ester moiety. The EIMS fragments at $\mathrm{m} / \mathrm{z}$ 194/196, corresponding to $\mathrm{C}_{8} \mathrm{H}_{5} \mathrm{BrN}$, corroborated the presence of a bromoindole group. These fragments, along with the fragments at $m / z$ 222/224 revealed the presence of a 3-carbonyl-bromoindole group, and established the connectivity between the 6-bromoindole moiety and the oxoacetic acid methyl ester moiety (Figure 2). Therefore, compound 1 was defined as (6-bromo- $1 \mathrm{H}$-indol-3-yl) oxoacetic acid methyl ester. Compound $\mathbf{1}$ was known as an intermediate in the synthesis of some marine natural products, such as didemnimides A and B [13], whereas it has not been reported from a natural source. Pyruvic acid derivatives are unusual natural products, and most of indole pyruvic acid derivatives were isolated from marine sponges [14-16] and ascidians [6]. 
Table 1. ${ }^{1} \mathrm{H}$ NMR Data of Compounds 1-6 (in DMSO- $d_{6}, 500 \mathrm{MHz}, \delta_{\mathrm{ppm}}$ ).

\begin{tabular}{|c|c|c|c|c|c|c|}
\hline position & 1 & 2 & 3 & 4 & 5 & 6 \\
\hline \multirow[t]{2}{*}{1} & & & & 12.19 & & 11.52 \\
\hline & & & & (brs) & & (br s) \\
\hline \multirow[t]{2}{*}{2} & 8.45 & 8.44 & 8.22 & 8.69 & 8.68 & 7.86 \\
\hline & (d, $J=2.0 \mathrm{~Hz}$ ) & (s) & (s) & (s) & (s) & (s) \\
\hline \multirow[t]{2}{*}{4} & 8.07 & 8.16 & 7.82 & 8.22 & 8.12 & 7.74 \\
\hline & (d, $J=8.0 \mathrm{~Hz}$ ) & (d, $J=7.0 \mathrm{~Hz}$ ) & (d, $J=8.0 \mathrm{~Hz}$ ) & (d, $J=6.0 \mathrm{~Hz}$ ) & (d, $J=8.5 \mathrm{~Hz}$ ) & (d, $J=8.5 \mathrm{~Hz})$ \\
\hline \multirow[t]{2}{*}{5} & 7.40 & 7.27 & 6.74 & 7.25 & 7.36 & 6.68 \\
\hline & $(\mathrm{dd}, J=8.0,2.0 \mathrm{~Hz}$ ) & (t, $J=7.0 \mathrm{~Hz})$ & (dd, $J=8.0,2.0 \mathrm{~Hz}$ ) & (t, $J=6.0 \mathrm{~Hz})$ & (dd, $J=8.5,2.0 \mathrm{~Hz}$ ) & (dd, $J=8.5,2.0 \mathrm{~Hz}$ ) \\
\hline \multirow[t]{2}{*}{6} & & 7.30 & & 7.25 & & \\
\hline & & $(\mathrm{t}, J=7.0 \mathrm{~Hz})$ & & (t, $J=6.0 \mathrm{~Hz})$ & & \\
\hline \multirow[t]{2}{*}{7} & 7.73 & 7.55 & 6.87 & 7.52 & 7.70 & 6.81 \\
\hline & (d, $J=2.0 \mathrm{~Hz})$ & (d, $J=7.0 \mathrm{~Hz}$ ) & (d, $J=2.0 \mathrm{~Hz})$ & (d, $J=6.0 \mathrm{~Hz})$ & (d, $J=2.0 \mathrm{~Hz})$ & (d, $J=2.0 \mathrm{~Hz})$ \\
\hline \multirow[t]{2}{*}{$-\mathrm{OCH}_{3}$} & 3.89 & $3.90(\mathrm{~s})$ & 3.87 & & & 3.76 \\
\hline & (s) & & (s) & & & (s) \\
\hline \multirow[t]{4}{*}{$-\mathrm{NH}_{2}$} & & & & 8.06 & 8.05 & \\
\hline & & & & (br s) & (br s) & \\
\hline & & & & 7.69 & 7.67 & \\
\hline & & & & (br s) & (br s) & \\
\hline \multirow[t]{2}{*}{$-\mathrm{OH}$} & & & & & & 9.17 \\
\hline & & & & & & (br s) \\
\hline
\end{tabular}<smiles>COC(=O)c1c[nH]c2cc(Br)ccc12</smiles>

1

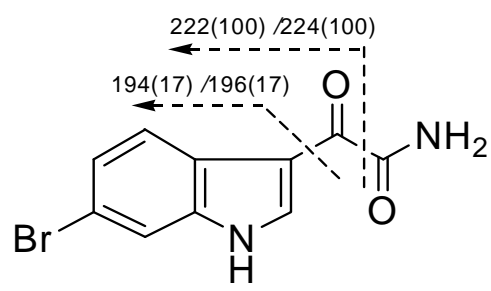

5<smiles>COC(=O)Cc1c[nH]c2cc(O)ccc12</smiles>

3<smiles>COI(C)(I)(I)C(=O)c1c[nH]c2cc(O)ccc12</smiles>

6

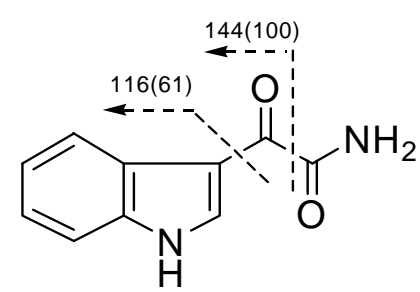

4

Figure 2. Key fragmentations of $[\mathrm{M}]^{+}$ions of $\mathbf{1}$ and 3-6 in LREIMS (relative intensity in parentheses). 
Compound 2 was isolated as a yellow, amorphous powder. The molecular formula was established as $\mathrm{C}_{11} \mathrm{H}_{9} \mathrm{NO}_{3}$ on the basis of the FABMS and NMR data. In the LRFABMS of 2, a $(\mathrm{M}+\mathrm{H})^{+}$ion was observed at $\mathrm{m} / \mathrm{z}$ 204. The main difference from compound $\mathbf{1}$ was lack of bromine atom on the indole ring. Therefore, compound 2 was defined as ( $1 H$-indol-3-yl) oxoacetic acid methyl ester. Compound 2 was known as an intermediate in the synthesis of natural products, such as didemnimides A and B [13], rebeccamycin, and 11-dechlororebeccamycin [17], whereas it has not been reported as a natural product.

Compound 3 was isolated as a yellow, amorphous powder. The molecular formula was established as $\mathrm{C}_{11} \mathrm{H}_{9} \mathrm{NO}_{4}$ on the basis of the EIMS and NMR data. In the LREIMS of $\mathbf{1}$, a (M) ${ }^{+}$ion was observed at $\mathrm{m} / \mathrm{z}$ 219. The main difference from compound 2 was an additional hydroxyl group on the indole ring. A singlet at $\delta_{\mathrm{H}} 8.22(1 \mathrm{H}, \mathrm{s}, \mathrm{H}-2)$, and a spin system comprised of signals at $\delta_{\mathrm{H}} 7.82(1 \mathrm{H}, \mathrm{d}, J=8.0, \mathrm{H}-$ 4), $6.74(1 \mathrm{H}, \mathrm{dd}, J=8.0,2.0, \mathrm{H}-5)$, and $6.87(1 \mathrm{H}, \mathrm{d}, J=2.0, \mathrm{H}-7)$, were observed in ${ }^{1} \mathrm{H}$ NMR spectrum. The HMBC correlations from H-2 $\left(\delta_{\mathrm{H}} 8.22\right), \mathrm{H}-5\left(\delta_{\mathrm{H}} 6.74\right)$, and $\mathrm{H}-7\left(\delta_{\mathrm{H}} 6.87\right)$ to C-3a $\left(\delta_{\mathrm{C}} 118.5\right)$, from $\mathrm{H}-2$ to C-3 $\left(\delta_{\mathrm{C}} 112.5\right)$ and C-7a $\left(\delta_{\mathrm{C}} 138.5\right)$, and from H-5 $\left(\delta_{\mathrm{H}} 6.74\right)$ to C-6 $\left(\delta_{\mathrm{C}} 154.4\right)$, indicated the presence of a 6-hydroxyindol-3-yl moiety. The EIMS fragments at $m / z 132$ and 160 corroborated the proposed structure (Figure 2). Therefore, compound 3 was defined as (6-hydroxy-1H-indol-3-yl) oxoacetic acid methyl ester. To the best of our knowledge, compound $\mathbf{3}$ has not been reported previously either from a natural source or as a synthetic product.

Compound 4 was isolated as a white, amorphous powder. The molecular formula was established as $\mathrm{C}_{10} \mathrm{H}_{8} \mathrm{~N}_{2} \mathrm{O}_{2}$ on the basis of the EIMS and NMR data. In the LREIMS of 3, a (M) ${ }^{+}$ion was observed at $\mathrm{m} / \mathrm{z}$ 188. The main difference from compound 2 was the presence of an oxoacetamide moiety instead of the oxoacetic acid methyl ester moiety. The ${ }^{13} \mathrm{C}$ signals at $\delta_{\mathrm{C}} 182.9(\mathrm{C}-8)$ and $\delta_{\mathrm{C}} 165.9(\mathrm{C}-9)$, the ${ }^{1} \mathrm{H}$ singlets at $\delta_{\mathrm{H}} 8.06$ and $\delta_{\mathrm{H}} 7.69$ (each $1 \mathrm{H},-\mathrm{NH}_{2}$ ) (Tables 1 and 2), along with the long-range correlation between $-\mathrm{NH}_{2}\left(\delta_{\mathrm{H}} 7.69\right)$ and $\mathrm{C}-8\left(\delta_{\mathrm{C}} 182.9\right)$, established an oxoacetamide moiety. The EIMS fragments at $\mathrm{m} / \mathrm{z} 116$ and 144 revealed the presence of a 3-carbonylindole group, and established the connectivity between the oxoacetamide moiety and the indole moiety (Figure 2). Thus, compound 4 was defined as (1H-indol-3-yl) oxoacetamide, which was also known as an intermediate in the synthesis of some marine natural products, such as arborescidines [18] and dihydrohamacanthins [19], but has not been isolated previously from a natural source.

Compound 5 was isolated as a yellow, amorphous powder. The molecular formula was established as $\mathrm{C}_{10} \mathrm{H}_{7} \mathrm{BrN}_{2} \mathrm{O}_{2}$ on the basis of the EIMS and NMR data. In the EIMS data of $\mathbf{5}$, a (M) ${ }^{+}$ion cluster was observed at $\mathrm{m} / \mathrm{z}$ 266/268. The main difference from compound 4 was an additional bromine atom on the indole ring. The fragments at $\mathrm{m} / \mathrm{z}$ 194/196 and 222/224 revealed the presence of 3-carbonylbromoindole group (Figure 2). Therefore, compound 5 was defined as (6-bromo- $1 H$-indol-3-yl) oxoacetamide, which was also reported as an intermediate in the synthesis of some natural products, such as arborescidines [18], dihydrohamacanthins [19], but has not been isolated from a natural source.

Compound 6 was isolated as colorless oil. The molecular formula was established as $\mathrm{C}_{10} \mathrm{H}_{9} \mathrm{NO}_{3}$ on the basis of the EIMS and NMR data. In the LREIMS of $\mathbf{6}$, a [M] $]^{+}$ion was observed at $\mathrm{m} / \mathrm{z} 191$. Analysis of the ${ }^{1} \mathrm{H},{ }^{13} \mathrm{C}$, COSY, HMBC, and HSQC data, allowed us to establish a 6-hydroxyindol residue as a partial structure of 6 . The long-range correlation from $\mathrm{H}-2\left(\delta_{\mathrm{H}} 7.86,1 \mathrm{H}, \mathrm{s}\right)$ and $-\mathrm{OCH}_{3}\left(\delta_{\mathrm{H}}\right.$ 3.76, 3H, s) to C-8 ( $\left.\delta_{\mathrm{C}} 164.8\right)$ established the presence of a formic acid methyl ester and the connectivity between the 6-hydroxyindol moiety and the carboxylic acid methyl ester. The EIMS 
fragments at $\mathrm{m} / \mathrm{z} 132$ and 160 corroborated the proposed structure (Figure 1). Therefore, compound 6 was defined as (6-hydroxy-1H-indol-3-yl) carboxylic acid methyl ester, which was known as an intermediate in the organic synthesis of a 5- $\mathrm{HT}_{4}$ receptor antagonist [20], but has not been reported from a natural source.

Compound 7 was also isolated as a yellow, amorphous powder. According to the MS and NMR data of 7, the main difference from 6 was lack of a hydroxyl group in the indole moiety. The MS and NMR data of 7 matched well with reported data [8], and was identified as (1H-indol-3-yl) carboxylic acid methyl ester which was previously reported from marine-derived bacteria [8] and fungi [21], and red alga [22], with cytotoxicity against K562 human chronic leukemia (MIC s $14.0 \mu \mathrm{g} / \mathrm{mL}$ ) [21].

Table 2. ${ }^{13} \mathrm{C}$ NMR Data of Compounds 1-6 (in DMSO- $d_{6}, 75 \mathrm{MHz}, \delta_{\mathrm{ppm}}$ ).

\begin{tabular}{crrrrrc}
\hline position & $\mathbf{1}$ & $\mathbf{2}$ & $\mathbf{3}$ & $\mathbf{4}$ & $\mathbf{5}$ & $\mathbf{6}$ \\
\hline 2 & 139.5 & 136.8 & 134.5 & 138.1 & 140.2 & 130.6 \\
3 & 112.5 & 112.7 & 112.5 & 112.0 & 112.0 & 106.3 \\
$3 \mathrm{a}$ & 124.8 & 125.5 & 118.5 & 126.1 & 125.6 & 118.7 \\
4 & 122.5 & 121.1 & 121.4 & 121.2 & 122.8 & 120.8 \\
5 & 125.3 & 122.8 & 112.2 & 122.4 & 125.0 & 111.6 \\
6 & 116.2 & 123.8 & 154.4 & 123.3 & 115.6 & 153.7 \\
7 & 115.5 & 112.4 & 97.7 & 112.4 & 115.6 & 97.2 \\
$7 \mathrm{a}$ & 138.6 & 138.4 & 138.5 & 136.2 & 140.0 & 137.4 \\
8 & 178.2 & 178.6 & $a$ & 182.9 & 180.0 & 164.8 \\
9 & 164.0 & 164.9 & 164.4 & 165.9 & 165.9 & \\
$-\mathrm{OCH}_{3}$ & 52.4 & 52.5 & 51.9 & & & 50.4 \\
\hline
\end{tabular}

${ }^{a}$ The carbonyl carbon signal was not detected due to low concentration of the NMR sample.

It is expected that ( $1 H$-indol-3-yl) oxoacetamide derivatives serve as intermediate for the biogenesis of co-occurring bisindole alkaloids, topsentins and hamacanthins [11,12] (Scheme 1). Schiff base formation between amino and carbonyl groups may (either via a or b) leads to the genesis of hamacanthin A ( I ) and topsentin ( II ) skeletons. Cleavage of the $\mathrm{C}-\mathrm{N}$ bond (c) in the topsentin skeleton, and successive Schiff base formation between newly generated amino group and the intact carbonyl group may lead to a genesis of hamacanthin B skeleton (III).

Compounds 1, 2, and 4-7 were evaluated for cytotoxicity against a panel of five human solid tumor cell lines. Compound 7 showed weak cytotoxicity to human lung cancer, human ovarian cancer, human skin cancer, human CNS cancer, and human colon cancer with $\mathrm{ED}_{50}$ values 24.1, 13.4, 15.2, 26.2, and $4.85 \mu \mathrm{g} / \mathrm{mL}$, respectively, while other compounds did not show significant activity $\left(E D_{50}>30 \mu \mathrm{g} / \mathrm{mL}\right)$. The $\mathrm{ED}_{50}$ values of doxorubicin against these tumor cell lines in the same experiment were $0.02,0.14,0.03,0.04$, and $0.10 \mu \mathrm{g} / \mathrm{mL}$, respectively. 


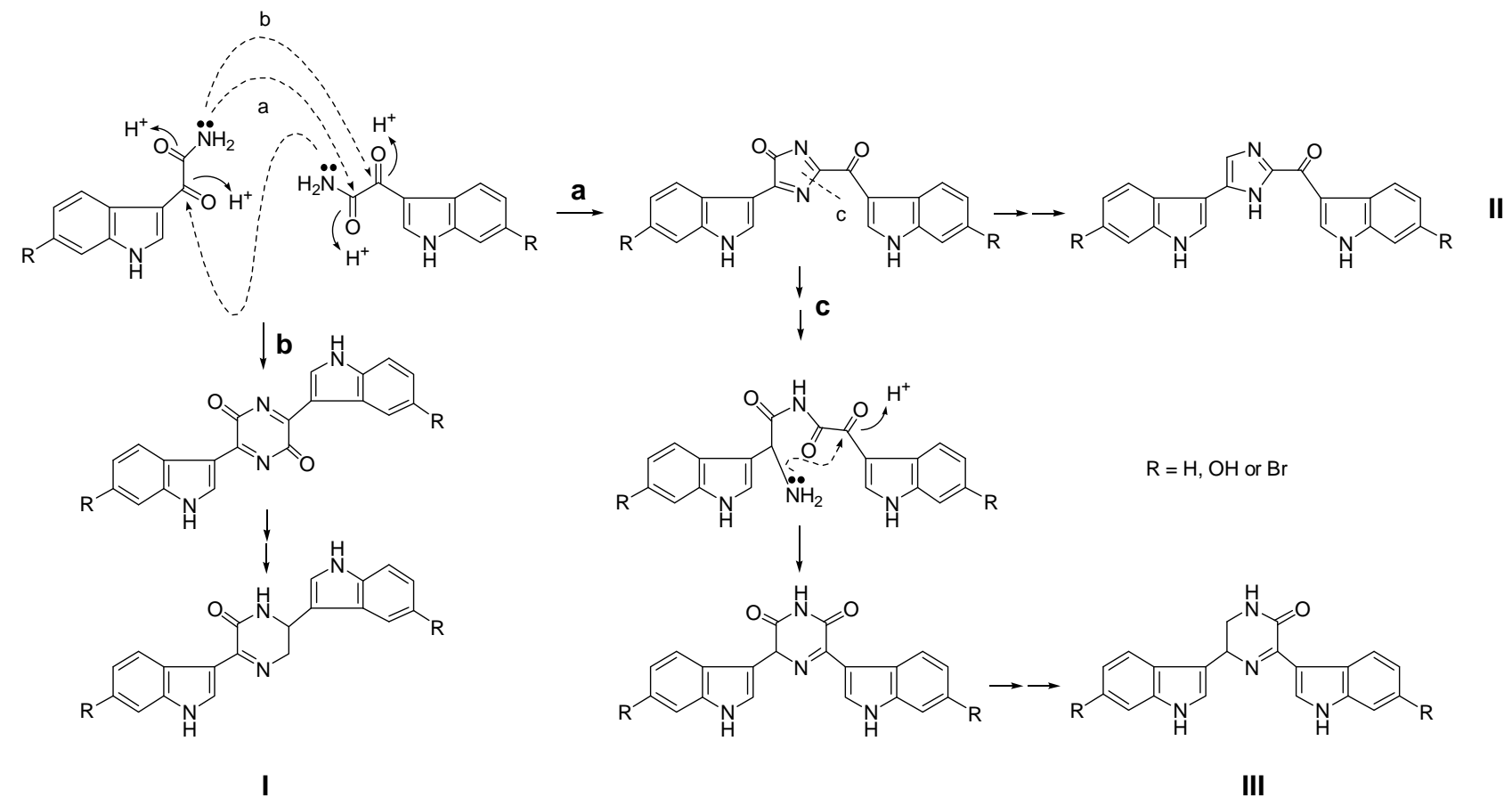

Scheme 1. Hypothetical biogenesis of topsentins and hamacanthins.

\section{Experimental}

\section{General Experimental Procedures}

${ }^{1} \mathrm{H}$ and ${ }^{13} \mathrm{C}$ NMR spectra were recorded on a Varian Unity 300 and Varian INOVA 500 instruments. Chemical shifts were reported with reference to the respective residual solvent or deuterated solvent peaks $\left(\delta_{\mathrm{H}} 2.5\right.$ and $\delta_{\mathrm{C}} 39.5$ for DMSO- $\left.d_{6}\right)$. FABMS data were obtained on a JEOL JMS SX-102A; EIMS data were obtained on a Shimadzu QP5050. HPLC was performed with an YMC ODS-H80 column (250 × $10 \mathrm{~mm}$ i.d., $4 \mu \mathrm{m}, 80 \AA)$ and C18-5E Shodex packed column $(250 \times 10 \mathrm{~mm}$ i.d., $5 \mu \mathrm{m}$, 100 Å) using a Shodex RI-71 detector.

\section{Animal Material}

The sponges were collected by hand using SCUBA (20 m depth) in October 2002, off the coast of Jeju Island, Korea. The collected sample was a loose association of two sponges Spongosorites sp. and Halichondria sp. The two sponges were separated and only Spongosorites sp. was subjected to chemical analysis. The morphology of the sponge was described elsewhere [11]. A voucher specimen (registry No. Spo. 44) is deposited at the Natural History Museum, Hannam University. Korea.

\section{Extraction and Isolation}

Evaluation was performed at Korea Research Institute of Chemical Technology. The frozen sponge $(0.8 \mathrm{~kg})$ was chopped into small pieces and extracted with $\mathrm{MeOH}$ at room temperature. The $\mathrm{MeOH}$ extract showed significant toxicity to brine shrimp larvae ( $\left.\mathrm{LD}_{50} 23.7 \mu \mathrm{g} / \mathrm{mL}\right)$. The $\mathrm{MeOH}$ extract was 
partitioned between $\mathrm{CH}_{2} \mathrm{Cl}_{2}$ and water. The $\mathrm{CH}_{2} \mathrm{Cl}_{2}$ layer was further partitioned between aqueous $\mathrm{MeOH}$ and $n$-hexane. Aqueous $\mathrm{MeOH}$ fraction was subjected to a reversed-phase flash column chromatography (YMC Gel ODS-A, $60 \AA$, 230 mesh) with a stepped gradient solvent system of 60 to $100 \% \mathrm{MeOH} / \mathrm{H}_{2} \mathrm{O}$ to afford 16 fractions. Fraction $2(0.80 \mathrm{~g})$, one of the bioactive fractions $\left(\mathrm{LD}_{50} 33.9\right.$ $\mu \mathrm{g} / \mathrm{mL}$ ), was subjected to a reversed-phase HPLC (YMC ODS-H80 column) eluting with 75\% MeOH to afford 13 sub-fractions. Compound $1(0.95 \mathrm{mg})$ was obtained by separation of the sub-fraction 2-8 on a reversed-phase HPLC eluting with 58\% MeCN. Compound 2 (2.2 mg) was obtained by separation of the sub-fraction 2-2 on a reversed-phase HPLC eluting with 35\% MeCN. The subfraction 2-1 was subjected to successive reversed-phase HPLC (YMC ODS-H80 column) eluting with 38\% MeCN, and further purification with 43\% MeCN (C18-5E Shodex packed column) to afford compounds 3 (0.4 mg), 4 (0.78 mg) and 6 (0.62 mg). Compounds 5 (1.2 mg) and 7 (3.3 mg) were obtained by separation of sub-fractions 2-5 and 2-4, respectively, on a reversed-phase HPLC (Shodex C18 M10E column) eluting with 42\% MeCN.

(6-Bromo-1H-indol-3-yl) oxoacetic acid methyl ester (1): yellow amorphous powder; ${ }^{1} \mathrm{H}$ NMR data, see Table $1 ;{ }^{13} \mathrm{C}$ NMR data, see Table 2; LREIMS m/z 281/283 (M) ${ }^{+}$.

(1H-Indol-3-yl)oxoacetic acid methyl ester (2): yellow amorphous powder; IR (film) $v_{\max } 3206$ (br), 1727, $1615 \mathrm{~cm}^{-1}$; UV (MeOH) $\lambda_{\max }(\log \in) 362$ (3.11), 262 (3.03) nm; ${ }^{1} \mathrm{H}$ NMR data, see Table $1 ;{ }^{13} \mathrm{C}$ NMR data, see Table 2; LRFABMS m/z $204(\mathrm{M}+\mathrm{H})^{+}$.

(6-Hydroxy-1H-indol-3-yl) oxoacetic acid methyl ester (3): yellow amorphous powder; ${ }^{1} \mathrm{H}$ NMR data, see Table 1; ${ }^{13} \mathrm{C}$ NMR data, see Table 2; LREIMS m/z $219(\mathrm{M})^{+}$.

(1H-Indol-3-yl) oxoacetamide (4): white amorphous powder; ${ }^{1} \mathrm{H}$ NMR data, see Table $1 ;{ }^{13} \mathrm{C}$ NMR data, see Table 2; LREIMS m/z $188(\mathrm{M})^{+}$.

(6-Bromo-1H-indol-3-yl) oxoacetamide (5): yellow amorphous powder; IR (film) $v_{\max } 3386,3211$, 1663, 1591, 1572, $1407 \mathrm{~cm}^{-1}$; UV (MeOH) $\lambda_{\max }(\log \in) 320$ (2.61), 275 (2.75), 258 (2.73), 212 (3.21) nm; ${ }^{1} \mathrm{H}$ NMR data, see Table $1 ;{ }^{13} \mathrm{C}$ NMR data, see Table 2; LREIMS m/z 266/268 (M) ${ }^{+}$.

(6-Hydroxy-1H-indol-3-yl) carboxylic acid methyl ester (6): colorless oil; ${ }^{1} \mathrm{H}$ NMR data, see Table 1; ${ }^{13} \mathrm{C}$ NMR data, see Table 2; LREIMS $\mathrm{m} / \mathrm{z} 191(\mathrm{M})^{+}$.

(1H-Indol-3-yl) carboxylic acid methyl ester (7): yellow amorphous powder; IR (film) $v_{\max } 3255$ (br), 1693, 1620, 1591, 1531, 1444, $1197 \mathrm{~cm}^{-1}$; UV (MeOH) $\lambda_{\max }$ (log $\in$ ) 349 (2.62), 240 (2.75); LREIMS m/z $175(\mathrm{M})^{+}$.

\section{Evaluation of Cytotoxicity}

A panel of five human solid tumor cell lines, human lung cancer, human ovarian cancer, human skin cancer, human CNS cancer, and human colon cancer, were used to screen cytotoxicity of the compounds based on an established protocol [11,12].

\section{Acknowledgement}

This study was supported by a grant from the Korea Research Foundation (2003-041-E 00331). The authors thank Prof. C. J. Sim, Hannam University, for the taxonomical work on the sponge. 


\section{References}

1. Kobayashi, J.; Murayama, T.; Ishibashi, M.; Kosuge, S.; Takamatsu, M.; Ohizumi, Y.; Kobayashi, H.; Ohta, T.; Nozoe, S.; Sasaki, T. Hyrtiosins A and B, new indole alkaloids from the Okinawan marine sponge Kyrtios erecta. Tetrahedron 1990, 46, 7699-7702.

2. Segraves N. L.; Crews, P. Investigation of brominated tryptophan alkaloids from two Thorectidae sponges: Thorectandra and Smenospongia. J. Nat. Prod. 2005, 68, 1484-1488.

3. Li, H.; Matsunaga, S.; Fusetani, N. Bioactive marine meabolites. Part 52. Simple antifungal metabolites from a marine sponge, Halichondria sp. Comp. Biochem. Phys. B: Biochem. Mol. Bio. 1994, 2, 261-264.

4. Rasmussen, T.; Christophersen, C.; Nielsen, P. H.; Rajagopal, R. Auxin activity of brominated indoles from the marine sponge Pseudosuberites hyalinus. J. Mar. Biotechnol. 1995, 2, 167-169.

5. Kobayashi, J.; Cheng, J.; Yamamura, S.; Sasaki, T.; Ohizumi, Y. Penaresin, a new sarcoplasmic reticulum Ca-inducer from the Okinawan marine sponge Penares sp. Heterocycles 1990, 31, 22052208.

6. Lindquist, N.; Fenical, W. Polyandrocarpamides A-D, novel metabolites from the marine ascidian Polyandrocarpa sp. Tetrahedron Lett. 1990, 31, 2521-2524.

7. Peters, L.; König, G. M.; Terlau, H.; Wright, A. D. Four new bromotryptamine derivatives from the marine bryozoan Flustra foliacea. J. Nat. Prod. 2002, 65, 1633-1637.

8. Zheng, L.; Yan, X.; Xu, J.; Chen, H.; Lin, W. Hymeniacidon perleve associated bioactive bacterium Psedomonas sp. NJ6-3-1. Appl. Biochem. Micro. 2005, 41, 29-33.

9. Li, Y.; Li, X.; Kim, D.; Choi, H.; Son, B. Indolyl alkaloid derivatives, $N_{b}$-acetyltrptamine and oxaline from a marine-derived fungus. Arch. Pharm. Res. 2003, 26, 21-23.

10. Van Lear, G. E.; Morton, G. O.; Fulmor, W. New antibacterial bromoindole metabolites from the marine sponge Polyfibrospongia maynardii. Tetrahedron Lett. 1973, 4, 299-300.

11. Bao, B.; Sun, Q.; Yao, X.; Hong, J.; Lee, C. O.; Sim, C. J.; Im, K. S.; Jung, J. H. Cytotoxic bisindole alkaloids from a marine sponge Spongosorites sp. J. Nat. Prod. 2005, 68, 711-715.

12. Bao, B.; Sun, Q.; Yao, X.; Hong, J.; Lee, C. O.; Cho H. Y.; Im, K. S.; Jung, J. H. Bisindole alkaloids of the topsentin and hamacanthin classes from a marine sponge Spongosorites sp. J. Nat. Prod. 2007, 70, 2-8.

13. Hughes, T. V.; Cava, M. P. Total synthesis of didemnimide A and B. Tetrahedron Lett. 1998, 39, 9629-9630.

14. Jimènez, C.; Quiñoà, E.; Adamczeski, M.; Hunter, L. M.; Crews, P. Novel sponge-derived amino acids. 12. Tryptophan-derived pigments and accompanying sesterterpenes from Fascaplysinopis reticulata. J. Org. Chem. 1991, 56, 3403-3410.

15. Dumdei, E.; Andersen, R. J. Igzamide, a metabolite of the marine sponge Plocamissma Igzo. J. Nat. Prod. 1993, 56, 792-794.

16. Bokesch, H. R.; Pannell, L. K.; McKee, T. C.; Boyd, M. R. Coscinamides A, B and C, three new bis indole alkaloids from the marine sponge Coscinoderma sp. Tetrahedron Lett. 2000, 41, 63056308.

17. Faul, M. M.; Winneroski, L. L.; Krumrich, C. A. Synthesis of rebeccamycin and 11dechlororebeccamycin. J. Org. Chem. 1999, 64, 2465-2470. 
18. Santos, L. S.; Pilli, R. A.; Rawal, V. H. Enantioselective total syntheses of (+)-arborescidine A, (-)-arborescidine B, and (-)-arborescidine C. J. Org. Chem. 2004, 69, 1283-1289.

19. Miyake, F. Y.; Yakushijin, K.; Horne, D. A. Synthesis of marine sponge bisindole alkaloids dihydrohamacanthins. Org. Lett. 2002, 4, 941-943.

20. Fedouloff, M.; Hossner, F.; Voyle, M.; Ranson, J.; Powles, J.; Riley, G.; Sanger, G. Synthesis and pharmacological activity of metabolites of the 5-HT 4 receptor antagonist SB-207266. Bioorg. Med. Chem. 2001, 9, 2119-2128.

21. Hu, S.; Tan, R.; Hong, K.; Yu, Z.; Zhu, H. Methyl indole-3-carboxylate. Acta Cryst. 2005, E61, 1654-1656.

22. Bano, S.; Ahmad, V. U.; Perveen, S.; Bano, N.; Shafiuddin; Shameel, M. Marine natural products; II. Chemical constituents of red alga Botryocladia Leptopoda. Planta Med. 1987, 53, 117-118.

Sample Availability: Not available.

(c) 2007 by MDPI (http://www.mdpi.org). Reproduction is permitted for noncommercial purposes. 